\title{
Psychometric Evaluation and Initial Validation of the Slovak Version of the Goal Adjustment Scale (GAS)
}

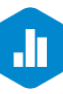

\author{
Beáta Ráczová ${ }^{\mathbb{D}}$, Pavol Kačmár ${ }^{\mathbb{D}}$, Monika Hricová \\ Department of Psychology, Faculty of Art, University of P. J. Safarik in Košice, Slovak Republic
}

\begin{abstract}
The aim of this study was to pilot test the psychometric properties of the Slovak version of the Goal Adjustment Scale (GAS) in a student sample. The research sample consisted of 636 students ( 355 secondary school pupils and 281 university students). The results of the confirmatory factor analysis supported the 2 -factor structure (as correlating factors) in the Slovak version of the scale. The internal consistency estimates of two factors (goal disengagement and reengagement) were relatively satisfactory. Regarding the convergent validity, the negative correlations between goal disengagement and dispositional optimism (LOT-R), hope (Snyder's Hope Scale) and self-regulation (SRQ) have been found. Moreover, significant positive correlations were only found in the case of goal reengagement and pathway as a factor of dispositional hope. However, the study did not support the relationship between adjustment capacities and subjective well-being measured through the frequency of positive and negative emotions (SEHP). One of the limitations of the research was that the test-retest reliability was not tested. It is considered important to perform further validation of the GAS in the future as the current results are preliminary. Nevertheless, the GAS seems to be an efficient tool in detecting adjustment strategies in the case of obstacles in the goal achieving process.
\end{abstract}

Key words: Goal Adjustment Scale GAS, psychometric properties, adaptive self-regulation

\section{Introduction}

In the scientific community, adaptive self-regulation is frequently associated with goal attainment, perseverance in goal achievement and goal commitment (Carver \& Scheier, 1998). However, personal goals can become difficult to achieve or are no longer even attainable in certain situations (Carver \& Scheier, 1990). Obstacles can threaten anticipated gains and the decision to disengage from personal goals might signal failure in reaching the desired intentions. Wrosch et al. (2003a) have proposed a goal adjustment theory that introduces goal adjustment capacities. These

Correspondence concerning this paper should be addressed to Beáta Ráczová, Department of Psychology, Faculty of Arts, P. J. Safarik University in Kosice, Slovak Republic. E-mail: beata.raczova@upjs.sk

Received March 19, 2020 
can be used in situations where individuals encounter obstacles in pursuing important goals or goals which have become unattainable. Goal adjustment capacities are made up of two strategies: goal-disengagement and goal reengagement, which are conceptualized as independent factors (Wrosch et al., $2003 a, b)$. Goal reengagement refers to the identification of alternative approaches and committing to the new goal pursuit (Wrosch et al., 2003). Goal disengagement allows an individual to expend effort on more attainable intentions (Wrosch et al., 2003a).

Both strategies are usually measured by a dispositional tool of goal adjustment capacity called the Goal Adjustment Scale (GAS, Wrosch et al., 2003a). The GAS has been widely used among the general (Soubrier, Esteve, \& Ramírez-Maestre, 2017) as well as specific population (e.g., cancer patients; Schroevers, Kraaij, \& Garnefski, 2011; Wrosch \& Sabiston, 2013). In our research, we decided to address young people (adolescents and young adults with an average age of 20), because according to the theory (Wrosch, Scheier, \& Miller, 2013) both late adolescence and transition to adulthood are important stages in the development of goal setting and goal adjustment capacity. In addition, recent research in this area has often focused on identifying impacts on subjective well-being (e.g., Wrosch et al., 2007; Barlow, Wrosch, \& McGrath, 2020).

The initial findings of the psychometric properties of the scales have shown satisfactory internal consistency (Cronbach's alpha was in the range of .79 to .84 for disengagement and .86 to .89 for reengagement) in three different research samples (undergraduates, young and older people, and parents of children with cancer) and in three different situations (Wrosch et al., 2003b). The correlation between the goal disengagement and reengagement scales was not significant in any of the three studies. Wrosch, Amir, and Miller
(2011) confirmed the high internal consistency of the scales several years later (Cronbach's alpha was .75 for goal-disengagement and .91 for reengagement). As in the original study, the subscales were not found to be highly correlated with each other $(.33, p<.01)$. Yet, a recent study by Van Damme et al. (2019) found that while there was a high level of internal consistency in the goal-disengagement subscale (Cronbach's alpha was .89), it was lower for the goal reengagement subscale (Cronbach's alpha was .63).

However, to the best of our knowledge, the factor structure of the original English version of the scale has not yet been verified and no valid and reliable measurement tool for goal adjustment reactions to goal obstacles exists in the Slovak Republic. Therefore, the first aim of this study is to extend the psychometric evaluation of the GAS scale by assessing the factor structure using Confirmatory Factor Analysis (CFA) and carry out an analysis of the internal consistency. In particular, the study aimed to corroborate the previous 2-factor theoretical model (both goal strategies as independent factors) (Wrosch et al., 2003b) and the model based on two correlating factors as indicated in more recent studies (e.g., Mens, Scheier, \& Wrosch, 2016; Barlow et al., 2020).

As to the validity, it should be mentioned that, to the best of our knowledge, the authors of the GAS did not carry out a specific validation study. At present, only the information on the identified relationships with selected variables are available dispersed across empirical literature. This includes the indicators of subjective well-being as well as markers of resilience (dispositional optimism and hope), which have been used in our study in the validation process. It should also be mentioned that the results of some studies have been more ambiguous. More specifically, in the case of the link between goal adjustment strategies and well-being, the results of the 
meta-analytical review (Barlow et al., 2020), by the authors of the GAS (e.g., Wrosch et al., $2003 a, b)$, showed that the adjustment of unattainable goals can be a necessary and adaptive self-regulation process. As the authors state, while goal disengagement can reduce the psychological difficulties associated with repeated failures, engaging in new goals can provide a life purpose, and achieving them could increase the positive aspects of well-being. Ramírez-Maestre et al. (2019) confirmed that well-being correlated positively with both setting abilities. For example, Barlow et al. (2020) have stated that goal reengagement is linked to higher levels of positive indicators and lower levels of negative indicators regarding psychological well-being. However, analyses also revealed contrasting findings: a negative correlation between well-being and goal disengagement and a positive relationship to reengagement (Nicholls et al., 2016), which the authors explain by less serious difficulties experienced by the respondents in achieving the goal.

In the case of relationships with optimism and hope the results are equally diverse. For example, Rasmussen et al. (2006) have shown a significant positive correlation with goal reengagement although not disengagement. On the other hand, Ramírez-Maestre et al. (2019) have found that optimism has high positive correlations with reengagement and a negative relationship with disengagement. Similarly, the results of the Hansen et al. (2014) study also show that higher levels of optimism and hope among students led them to overcome obstacles rather than give up goals. This also explains how optimists generally expect positive results, which may offset the inability to disconnect from unattainable goals. Generally, according to the motivational theory of life-span development by Heckhausen et al. (2010), people choose to engage with a goal when the opportunities for goal attainment are perceived as favorable and conversely they choose to goal disengage when the opportunities are perceived as unfavorable, which is conceptually closely linked to hope and optimism. However, the authors emphasize, that in this case it also plays the role of characteristics of goals (unattainable goals/only difficulties in achieving the goal).

Based on the findings mentioned above, the second aim of the present study was to verify the construct (specifically the convergence) validity of the GAS: positive relationships were expected between both goal adjustment strategies and positive state of mind (as a positive indicator of well-being) and self-regulation; and between goal reengagement and dispositional optimism and hope. Negative relationships were expected between both goal adjustment strategies and negative state of mind (as a negative indicator of well-being) and between goal disengagement and optimism and hope.

\section{Methods}

\section{Research Sample}

The study sample consisted of 636 participants $^{1}$ (58\% female, with an average age of

${ }^{1}$ In order to justify the sample size in the CFI, power analysis with "A-priori Sample Size for Structural Equation Models module" (Soper, 2019) was used. The parameters were set to: a) desired statistical power level $=.80$; b) probability level (type 1 error) = $.05 ; \mathrm{c}$ ) number of latent variables $=2$; d) number of observed variables $=10$; and e) small-to medium effect size of interest $(r=.17-.18)$. Based on this, the recommended minimum sample size would be estimated to be 280-316 participants per cross-validation train/test subsamples ( $N=560-632$ in total). To provide sample size justification for validation phase, according to power analysis (Zhang \& Yuan, 2018), to find correlation with magnitude of .17 - .20; power of .8; and alpha of .05, $N=193-268$ participants should be sufficient. 
20 years; $S D=4.3)$. The total sample comprised two subsamples: secondary school pupils ( $N=$ $355 ; 52 \%$ female, with an average age of 16.8 ; $S D=1.3)$ and university students $(N=281 ; 67 \%$ female, with an average age of 23.6 years; $S D=$ 3.8). Students were informed that participation in the research is voluntary and anonymous and that they can terminate their participation at any time. After reading and agreeing to information regarding the research, they continued to the full questionnaire.

\section{Measures}

The Goal Adjustment Scale (GAS, Wrosch et al., 2003b) is a 10-item scale that was designed to assess how people usually react to goal obstacles across life domains. Items are scored on a 5-point Likert-type scale from 1 - strongly disagree to 5 - strongly agree. Individuals rate how they usually react if they have obstacles in achieving an important goal and can no longer pursue that goal. Wrosch et al. (2003b) have previously indicated that the GAS has two distinct factors; a goal disengagement scale (4 items, e.g., "It's easy for me to reduce my effort towards the goal.") and goal reengagement scale (6 items, e.g., "I convince myself that I have other meaningful goals to pursue."). The subscales are indexed by computing the mean scores of the relevant subscale items (for both subscales separately). The original English version of the questionnaire was translated into Slovak by two independent Slovak translators and translated back into English. Any discrepancies or ambiguities concerning the translation were subsequently discussed with a native English speaker. Both versions were compared and unified (Slovak versions of the GAS scale were added to the Appendix).

The Slovak adaptation of Snyder's Scale of Hope (Halama, 2001) identifies hope as a feature in adults and adolescents from 15 years of age. The Hope scale consists of 12 items and two subscales (4 items are distracters); Agency (McDonald's $\omega=.71$ ) and Pathway (McDonald's $\omega=.72$ ). The Agency items represent cognitive will and assess one's motivated state to reach desired goals (e.g., "I energetically pursue my goals."). The Pathway items represent ways to meet goals or other words to assess the sense that one will be able to successfully generate a plan to attain them (e.g., "I can think of many ways to get out of the jam.").

Dispositional optimism was measured by an adapted version of the Life Orientation Test Revised (LOT-R) (Köverová \& Ferjenčík, 2013), which consists of 10 items ( 3 items assess optimism, e.g., "Overall, I expect more good things to happen to me than bad." 3 items assess pessimism along with four filler items, e.g., "I hardly ever expect things to go my way."). A total score can be calculated by adding the optimism and inverted pessimism score (McDonald's $\omega=.70$ ).

Self-regulation was measured by an adapted version of the Short Self-Regulation Questionnaire (SRQ, Šebeňa et al., 2018) and consists of 23 items (e.g., "I usually keep track of my progress toward my goals."). The Slovak version of the scale is used as one-dimensional (McDonald's $\omega=$.74).

The emotional component of well-being (i.e., frequency of experiencing positive and negative emotions) was measured by the Emotional Habitual Subjective Well-being Scale (SEHP) (Džuka \& Dalbert, 2002). The scale consists of 10 items and has two separate subscales; Negative (frequency of experiencing negative emotions such as guilt, shame; McDonald's $\omega=.85$ ) and Positive (frequency of experiencing positive emotions such as joy, happiness; McDonald's $\omega=.79$ ).

\section{Statistical Analysis}

The Confirmatory Factor Analysis (CFA) was conducted in $R$ ( $R$ Core Team, 2017) with 
packages: MVN, MASS, Lavaan, SemPlots and SemTools. The code and data can be found at the following link:

https://osf.io/kv8x7/?view only=54dd5c7ecaa5470988ce930a39f7733d

The missing values were handled using the listwise deletion procedure. The histograms, skewness, kurtosis, Shapiro-Wilk's test and Lilliefors test as well as a Mardia test were examined to assess normality. The multivariate outliers were handled with the Minimum Covariance Determinant version of Mahalonobis distance (MCD 75) (Leys et al., 2019).

An Unweighted Least Squares (ULS) estimation method, based on the polychoric correlation matrix (see Appendix) with robust correction - mean- and variance-adjusted unweighted least squares (ULSMV), was used to address the Likert scale categorical nature of the data in the CFA (see e.g., Kogar \& Kogar, 2015).

The appropriateness of the model fit was assessed by Chi-Square $\left(\chi^{2}\right)$, Root Mean Square Error of Approximation (RSMEA), Comparative Fit Index (CFI), Tucker-Lewis index (TLI), and the Standardized Root Mean Square Residual (SRMR) as recommended by Kline (2016). The cut-off scores were selected based on recommendations provided by Hooper, Coughlan, \& Mullen (2008): relative $\chi^{2}\left(\chi^{2} / d f\right)=2: 1 ; C F I>$ .95; SRMR < .08; RMSEA < 07.

The internal consistency was assessed through the Cronbach's alpha (based on the polychoric matrix) and McDonald's omega coefficients. The interpretational benchmarks were set to $>.89$ excellent, .80 to .89 good, .70 to .79 acceptable, and .60 to .69 poor but marginally acceptable in shorter scales as measure of internal consistency of the scale is partly determined by the number of items, and $<.50$ insufficient (Field, 2017).

In order to corroborate convergent validity, non-parametric Kendall's tau-b correlation coefficient with Bonferroni correction con- trolling for Family-Wise Error rate and Benjamini and Hochberg procedure controlling for False Discovery Rate were used. Moreover, the Bayes factor was used to provide information regarding the strength of the evidence for the alternative over the null hypothesis and vice versa. Two-sided tests were used. The analysis was carried out in Jamovi 1.1.

\section{Results}

\section{Factor Structure}

While the skewness and kurtosis were within the acceptable range, the Shapiro-Wilk's test and Lilliefors test were found to be significant. Moreover, the data did not have multivariate normal distribution as indicated by the Mardia test (Mardia Skewness $=614$; Mardia Kurtosis $=.18$; both $p<.001$; the descriptive analysis for every item can be found on-line at OSF). Prior to doing the CFA, the listwise deletion procedure dealt with the missing values and the multivariate outliers were identified and dealt with using the Minimum Covariance Determinant version of Mahalonobis distance (MCD 75) (Leys et al., 2019). Furthermore, a cross-validation procedure was implemented. For this purpose, participants were randomly assigned to a train and test subtest and the modified model, based on the modification indices proposed in the train sample, was evaluated in the test sub-sample. Note that although the results with both ULS and ULSMV will be reported, only the more stringent method with robust corrections will be interpreted.

Firstly, the theoretically driven model was evaluated with both (A) the orthogonal factors (as proposed by the theory) (Model 1) and (B) correlated factors (as some empirical evidence has indicated) (Model 2) (see Figures 1 and 2).

As summarized in Table 1, using the polychoric correlation matrix and ULSMV in the 
train sample, it was found that the orthogonal model (Model 1) did not provide an acceptable model fit as the goodness-of-fit indices were far beyond the conventional cut-off scores (Hooper et al., 2008) $\left[\chi^{2}(35)=181.53\right.$, $p<.001 ; \chi^{2} / d f$-ratio $=5.19 ; \mathrm{CFI}=.895 ; \mathrm{SRMR}=$ .119 ; and RMSEA $\left.=.118, p_{\text {RMSEA }}<.001\right]$. In comparison, the alternative model with the correlated factors (Model 2) provided a better fit $\left[\chi^{2}(34)=124.6, p<.001 ; \chi^{2} / d f\right.$-ratio $=$ 3.36; $\mathrm{CFI}=.935$; SRMR $=.070$ and RMSEA = $\left..094, p_{\text {RMSEA }}<.001\right]$. In fact, the $\chi^{2}$ difference between the two models was significant (23.483 (1), $p<.001)$. The intercorrelation between the latent factors was .32, which indicates that these two factors could be considered as distinct (less than .90), but still related - the medium effect size according to Cohen's classic benchmarks. This pattern of results was also replicated in the test sample where the model provided an acceptable fit according to some criteria $\left[\chi^{2}(34)=91.29, p<.001\right.$; $\chi^{2} / d f$-ratio $=2.69 ; \mathrm{CFI}=.963 ;$ SRMR $=.052 ;$ and RMSEA $\left.=.075, p_{\text {RMSEA }}<.001\right]$. Thus, in line with existing empirical evidence (e.g., Mens et al., 2016; Barlow et al., 2020), the model with the correlated factors is preferred over the model with the orthogonal factors.

Nevertheless, when the robust corrected estimation method is used and interpreted, the model fit for some fit indices is still borderline or even beyond the more stringent criteria especially considering robust corrected values (significant $\chi^{2}$; RMSEA above .70). Thus, the modification indices were examined in the default model with the correlated factors in the test sample (Model 2) to see if the model could be improved. Based on the modification indices (MI beyond 15), one error covariance was proposed and was added between the third and sixth items. This could be conceptually justified due to the fact that these are the only two items that should be reversed. In order to test this slight-

Table 1 Model Fit Indices

\begin{tabular}{|c|c|c|c|c|c|c|c|c|c|c|}
\hline \multirow[t]{2}{*}{ Subtest } & & & \multirow[b]{2}{*}{$\chi^{2}$} & \multirow[b]{2}{*}{$d f$} & \multirow[b]{2}{*}{$p$} & \multirow[b]{2}{*}{$\chi^{2} / \mathrm{df}$ CFI } & \multirow[b]{2}{*}{ SRMR } & \multicolumn{3}{|c|}{ RMSEA } \\
\hline & & & & & & & & RMSEA & $\begin{array}{l}\mathrm{Cl} \text { lower } \\
-\mathrm{Cl} \text { upper }\end{array}$ & $p$ close \\
\hline \multirow{4}{*}{$\begin{array}{l}\text { Train } \\
\text { subtest } \\
(n=302)\end{array}$} & \multirow{2}{*}{$\begin{array}{l}\text { Model } 1 \\
\text { Orthogonal } \\
\text { factors }\end{array}$} & ULS & 235.67 & 35 & na & 6.74 .900 & .119 & .138 & $.122-.155$ & .001 \\
\hline & & ULSMV & 181.56 & 35 & .001 & 5.19 .895 & .119 & .118 & 101 - 135 & .001 \\
\hline & \multirow{2}{*}{$\begin{array}{l}\text { Model } 2 \\
\text { Correlated } \\
\text { factors }\end{array}$} & ULS & 76.03 & 34 & na & 2.24 .979 & .070 & .064 & $.083-.109$ & .068 \\
\hline & & ULSMV & 124.61 & 34 & .001 & 3.66 .935 & .070 & .094 & $.077-112$ & .001 \\
\hline \multirow{4}{*}{$\begin{array}{l}\text { Test } \\
\text { subtest } \\
(n=302)\end{array}$} & \multirow{2}{*}{$\begin{array}{l}\text { Model } 2 \\
\text { Correlated } \\
\text { factors } \\
\end{array}$} & ULS & 44.82 & 34 & & 1.32 .994 & .052 & .033 & $.001-.056$ & .877 \\
\hline & & ULSMV & 91.29 & 34 & .001 & 2.69 .963 & .052 & .075 & $.057-.940$ & .014 \\
\hline & \multirow{2}{*}{$\begin{array}{l}\text { Model } 3 \\
\text { Modified } \\
\text { model } \\
\text { (covariation } \\
\text { added) }\end{array}$} & ULS & 37.05 & 32 & na & 1.16 .998 & .060 & .020 & $.000-.048$ & .961 \\
\hline & & ULSMV & 78.28 & 33 & .001 & 2.37 .971 & .047 & .068 & $.048-.087$ & .065 \\
\hline
\end{tabular}

Note. ULS means Unweighted Least Squares estimator; ULSMV means Mean-and variance-adjusted unweighted least squares estimator (Robust unweighted least squares). 


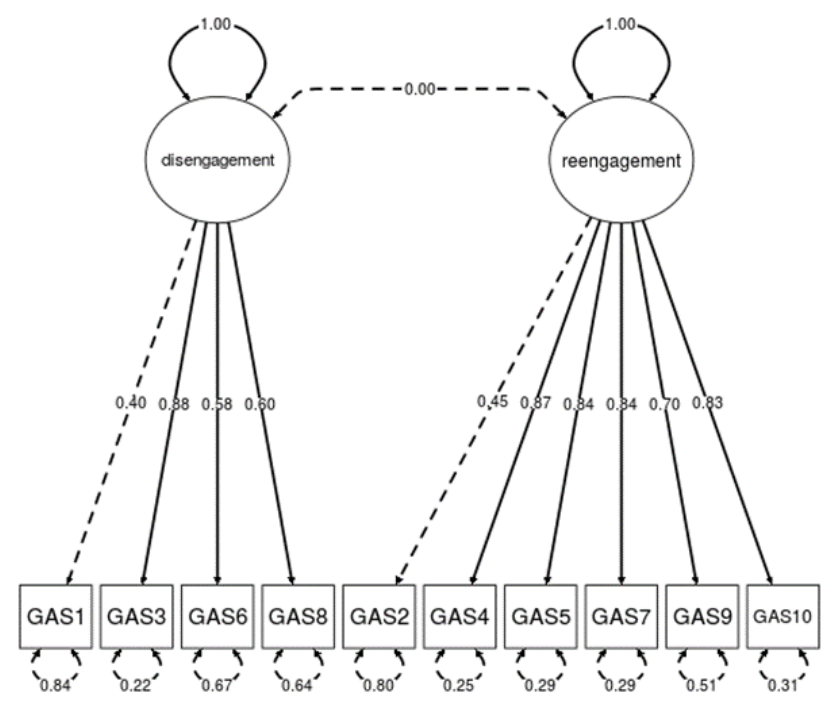

Figure 1 Path diagram - Orthogonal factors (Model 1)

Note. Numbers below items represent error; numbers above items represent standardized estimates; and circles represent latent factors.

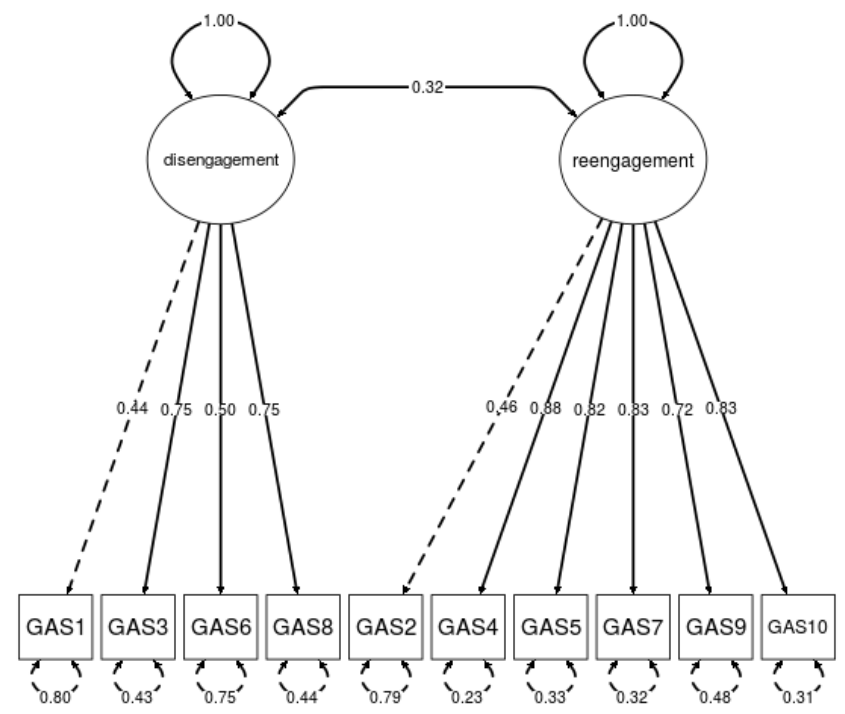

Figure 2 Path diagram - Correlated factors (Model 2)

Note. Numbers below items represent error; numbers above items represent standardized estimates; and circles represent latent factors. 


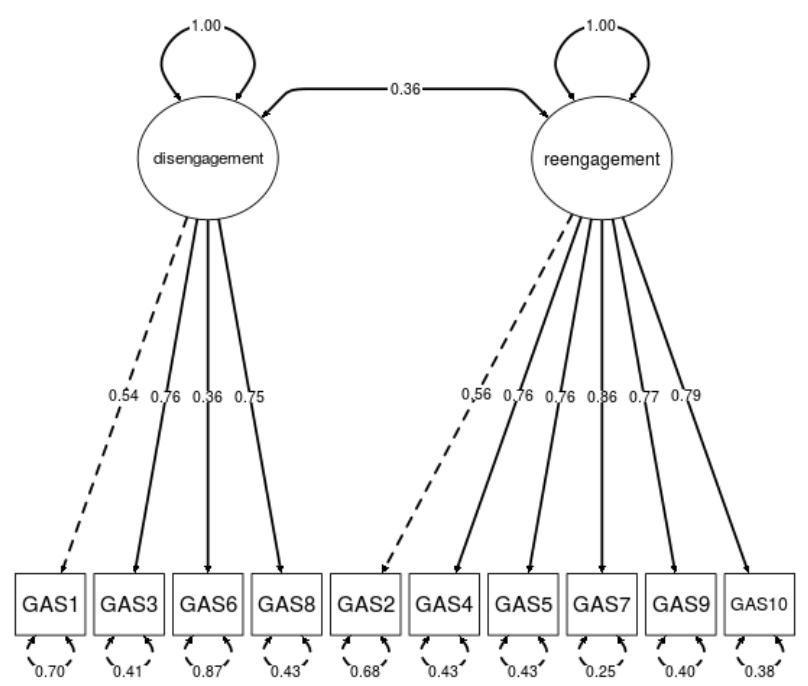

Figure 3 Path diagram - Correlated factors (Model 2) replicated on test sample

Note. Numbers below items represent error; numbers above items represent standardized estimates; and circles represent latent factors.

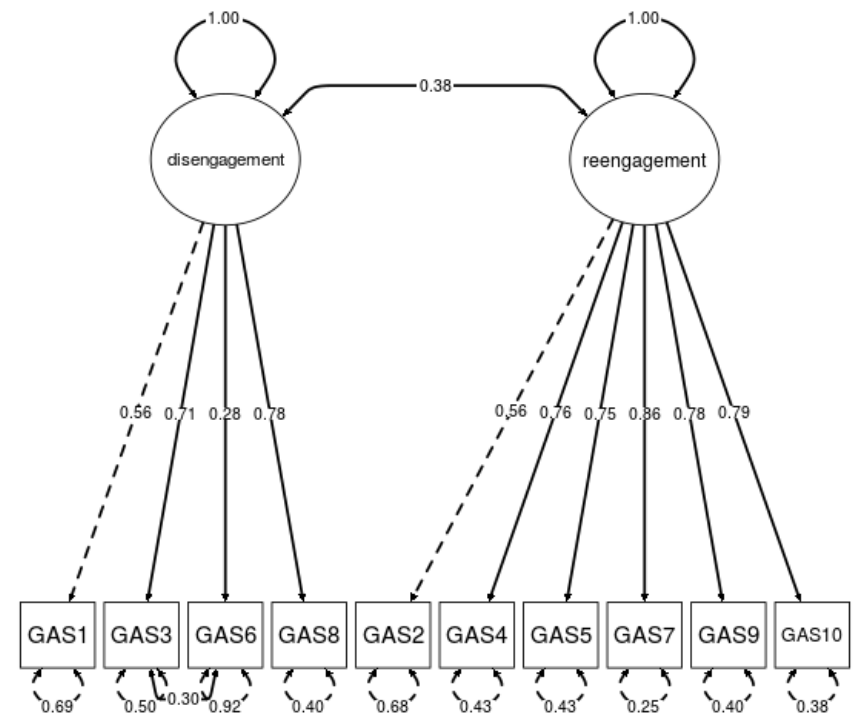

Figure 4 Path diagram - Correlated factors with covariance between errors replicated on test sample (Model 3)

Note. Numbers below items represent error; numbers above items represent standardized estimates; and circles represent latent factors. 
ly modified Model, Model 3 was tested on the test subsample to ensure that overfitting would not be an issue. The model not only provided a better fit in the test sample than the previously preferred non-modified model $\left(\chi^{2}\right.$ difference between this modified model and the default model with correlated factors was $14.25(1), p<.001$ ), but (except the statistically significant chi square statistics) provided relatively acceptable fit according to Hooper et al. (2008) $\left[\chi^{2}(32)=78.28, p<\right.$ $.001 ; \chi^{2} / d f$-ratio $=2.37 ; \mathrm{CFI}=.97 ; \mathrm{SRMR}=$ $.049 ;$ RMSEA $\left.=.068 ; p_{\text {RMSEA }}<.065\right]$. Thus, this modified model is preferred over the previous one and is considered to be relatively acceptable according to above mentioned criteria.

\section{Internal Consistency}

An analysis of the internal consistency (see Table 2) indicated that Cronbach's alpha based on polychoric correlations was within the acceptable range (more than .70) (Field,
2017). Nevertheless, the value of Omega was slightly below .70 for the disengagement scale. Although $>.60$ could be considered to be within the acceptable range especially for scales with fewer items, given that internal consistency is determined by the number of items (Field, 2019), factor loadings were further analyzed as Cronbach's alpha assumes tau equivalence and thus specific items could be problematic in the present case.

\section{Factor Loadings}

An analysis of the factor loadings across all the models indicated that three items (two of them from the disengagement factor) had lambda $<.70$ (note that the value .70 could be considered as a strong factor loading). However, these values differed across the models, ranging from .58 to .28 . It is important to mention that a lambda value of .30 could be considered as the threshold for excluding an item in a scale. One item (item 6) was found to be below this threshold, but it

Table 2 Internal Consistency

\begin{tabular}{|c|c|c|c|c|}
\hline Subtest & Model & & $\begin{array}{c}\text { Cronbach's } \\
\text { alpha }\end{array}$ & Omega total \\
\hline \multirow{6}{*}{$\begin{array}{l}\text { Train } \\
\text { subtest } \\
(n=302)\end{array}$} & \multirow{3}{*}{$\begin{array}{l}\text { Orthogonal } \\
\text { factors }\end{array}$} & Disengagement & .70 & .67 \\
\hline & & Reengagement & .89 & .87 \\
\hline & & Total & & .71 \\
\hline & \multirow{3}{*}{$\begin{array}{l}\text { Correlated } \\
\text { factors }\end{array}$} & Disengagement & .70 & .66 \\
\hline & & Reengagement & .89 & .87 \\
\hline & & Total & & .84 \\
\hline \multirow{6}{*}{$\begin{array}{l}\text { Test } \\
\text { subtest } \\
(n=302)\end{array}$} & \multirow{3}{*}{$\begin{array}{l}\text { Correlated } \\
\text { factors }\end{array}$} & Disengagement & .70 & .66 \\
\hline & & Reengagement & .88 & .86 \\
\hline & & Total & & .84 \\
\hline & \multirow{3}{*}{$\begin{array}{l}\text { Modified } \\
\text { model } \\
\text { (covariation added) }\end{array}$} & Disengagement & .70 & .61 \\
\hline & & Total & .88 & .86 \\
\hline & & Reengagement & & .83 \\
\hline
\end{tabular}


was decided not to drop it from the model. There were several reasons for this decision, but the most important are: A) the factor loading was only slightly below this threshold; B) the measure of internal consistency would not improve rapidly after the deletion of the item.

\section{Evidence in Favor of Convergent Validity}

Table 3 shows that according to Kendall's tau- $b$ correlation coefficient, there was a statistically significant negative correlation between Goal disengagement and Hope Scale Agency Subscale $\left(\tau_{\mathrm{b}}=-.22, p<.001, \mathrm{BF}_{10}=\right.$ 1.12e+7, $\left.\mathrm{BF}_{01}=8.96 \mathrm{e}-8\right)$, Hope Scale Pathway Subscale $\left(\tau_{\mathrm{b}}=-.17, p<.001, \mathrm{BF}_{10}=9699.80\right.$, $\left.\mathrm{BF}_{01}=1.03 \mathrm{e}-4\right)$, Dispositional optimism $\left(\tau_{\mathrm{b}}=\right.$ -.11, $\left.p=.004, \mathrm{BF}_{10}=7.95, \mathrm{BF}_{01}=0.13\right)$, and SRQ $\left(\tau_{\mathrm{b}}=-.39, p<.001, \mathrm{BF}_{10}=2.73 \mathrm{e}+18, \mathrm{BF}_{01}\right.$ $=4.21 \mathrm{e}-19)$. According to the Bayes factor, there was moderate to extreme evidence for the alternative hypothesis over the null. However, there was not a statistically significant relationship between Goal Disengagement and SEHP for either Negative $\left(\tau_{\mathrm{b}}=-.03, p=\right.$ $.420, \mathrm{BF}_{10}=.11, \mathrm{BF}_{01}=8.77$ ) or Positive state of mind $\left(\tau_{\mathrm{b}}=-.001, p=.953, \mathrm{BF}_{01}=.08, \mathrm{BF}_{10}\right.$ $=12.72$ ). According to the Bayes factor, there was moderate to strong evidence for the null hypothesis.

Additionally, there was a statistically significant positive correlation between Goal re-en- gagement and Hope Scale Pathway Subscale $\left(\tau_{\mathrm{b}}=.12, p=.001, \mathrm{BF}_{10}=23.44, \mathrm{BF}_{01}=.04\right)$. There is strong evidence for the alternative hypothesis over the null. However, there were no statistically significant correlations between Goal reengagement and Hope Scale Agency Subscale $\left(\tau_{\mathrm{b}}=.05, p=.148, \mathrm{BF}_{10}=.23\right.$, $\left.\mathrm{BF}_{01}=4.44\right)$, Dispositional optimism $\left(\tau_{\mathrm{b}}=.04\right.$, $\left.p=.337, \mathrm{BF}_{10}=.12, \mathrm{BF}_{01}=8.49\right), \mathrm{SRQ}\left(\tau_{\mathrm{b}}=.02\right.$, $\left.p=.580, \mathrm{BF}_{01}=.09, \mathrm{BF}_{10}=10.65\right)$, and Negative $\left(\tau_{\mathrm{b}}=.02, p=.602, \mathrm{BF}_{10}=.09, \mathrm{BF}_{01}=10.96\right)$ or Positive $\left(\tau_{\mathrm{b}}=.02, p=.508, \mathrm{BF}_{10}=.10, \mathrm{BF}_{01}\right.$ $=9.93$ ) state of mind. According to the Bayes factor, there was a moderate to strong evidence for the null.

Moreover, as the type I error increased due to multiple comparisons, two procedures aimed at controlling Family-wise Error rate were carried out. When controlling for the False Discovery Rate via the Benjamini and Hochberg procedure, all 5 correlations remained significant. In line with this, even when controlling for Family-Wise Error rate using the more stringent Bonferroni correction, all 5 of the 12 correlations remained statistically significant as for the 12 comparisons, the corrected critical $p$-value is .0042 and all $p$-values are below this criterion.

\section{Discussion and Conclusion}

The main aim of the present study was to provide the results from a pilot study focused on

Table 3 Kendall's tau-b correlation coefficient

\begin{tabular}{lllllcc}
\hline & $\begin{array}{c}\text { Hope } \\
\text { Agency }\end{array}$ & $\begin{array}{c}\text { Hope } \\
\text { Pathway }\end{array}$ & LOTR & SRQ & $\begin{array}{c}\text { SEHP } \\
\text { Negative }\end{array}$ & $\begin{array}{c}\text { SEHP } \\
\text { Positive }\end{array}$ \\
\hline Goal disengagement & $-.22^{* * *}$ & $-.17^{* * *}$ & $-.11^{* *}$ & $-.39 * * *$ & -.03 & .01 \\
\hline Goal reengagement & .07 & $.12^{* *}$ & .05 & -.02 & .02 & .03 \\
\hline
\end{tabular}

Note. Hope - Hope Scale; LOTR - Life Orientation Test - Revised; SRQ - Short Self-Regulation Questionnaire; SEHP - Emotional Habitual Subjective Well-being Scale - negative and positive state of mind.

${ }^{*} p<.05, * * p<.01, * * * p<.001$ 
the examination of a factor structure, internal consistency and convergent validity of the Slovak version of the GAS (Wrosch et al., 2003) in a sample of young people (university undergraduates and secondary school pupils).

In accordance with the theoretical basis, two models were examined. The first model was based on the original conceptualization of goal adjustment (Wrosch et al., 2003b) and assumed that there were 2 independent factors. The second tested model was in line with several recent research findings, e.g., Mens et al. (2016), Barlow et al. (2020), and Soubrier et al. (2017), and assumed 2 correlated factors $(r=.30, p<.01)$. The authors of these studies interpreted the correlation between the factors as low, however, a more nuanced approach is necessary when interpreting a correlational coefficient of this magnitude. Cohen has considered .3 as medium effect size, although, a lack of empirical support and frame of reference can be traced for this distinction (Funder \& Ozer, 2019). When considering potential consequences in a long run, Funder and Ozer (2019, p. 166) have argued that $r=.2$ could be considered a medium effect and .3 even as a large effect that "is potentially powerful in both the short and the long run".

Irrespective of the interpretation of the magnitude, there is a possibility that the two dimensions might interact. For instance, the authors of the Goal Adjustment theory (Wrosch et al., 2003b) have proposed that reengagement capacity is especially important in the context of high disengagement. Indeed, disengagement from important personal goals, without subsequent reengagement, could leave an individual with no personally meaningful goals left to pursue and this interaction has been observed in samples of older adults (Wrosch et al., 2007) as well as patients who have had a suicidal episode ( $O^{\prime}$ Connor et al., 2009) and have few available alternative goals and fewer goals opportunities, in general. These findings show that these individuals may be especially vulnerable to the loss of personal goals and age could be an important factor (Mens et al., 2016).

The first part of the present study presents confirmatory factor analyses indicating a lack of empirical support for the original theoretical model with two independent factors (Wrosch et al., 2003b). However, when considering more stringent criteria, the second model with 2 correlated factors was still not fully acceptable as model fit was beyond recommended benchmarks (Hooper et al., 2008). Therefore, a slightly modified model was proposed instead, where covariance was added between reverse coded items (variables 3 and 6). According to the criteria given by Hooper et al. (2008), the modified model showed to be the most suitable of the tested models and relatively acceptable. One of the exceptions was the statistically significant Chi-quadrant value showing a non-zero residue value. However, Halama (2011), for instance, states that this criterion is very strict especially for larger samples.

In the second part of the present study, the focus was on corroborating the internal consistency and convergent validity of the Slovak version of the scale. First, according to Cronbach's alpha coefficient based on the polychoric correlations, the tested models provided satisfactory internal consistency for both factors (goal disengagement and reengagement). The resulting Cronbach's alpha coefficient was comparable to the results of the original version of the questionnaire by Wrosch et al. (2003b). Moreover, several other studies such as Wrosch et al. (2011) and the adaptation study of the Chinese version of the GAS (Lam et al., 2016) have found similar values of internal consistency for the scale. However, some studies have noted a lower internal consistency value for some of the 
subscales (e.g., in Soubrier et al., 2017, Cronbach's $\alpha$ for the goal disengagement was .63). In line with this, the results of the current analyses have shown that the internal consistency estimated by Omega was below .70 for the goal disengagement scale. The problematic item was not removed, and it is, therefore, necessary to be aware that if the scale is used in practice, at least in some cases, the goal disengagement scale may show a lower degree of internal consistency.

Additionally, according to the original concept, both strategies of goal management capture people's general reactions to unattainable goals (Wrosch et al., 2007). It is, however, important to note that here has been a slight shift in this aspect in the current research, as more general instruction was used in the present research and concerned situations where individuals encounter obstacles in pursuit of important goals. Therefore, we focus on goals that have become really difficult to attain rather than strictly unattainable. This approach is in line with the current direction of research in the field of self-regulation to clarify disruptive factors in achieving a goal and the possibility of revising the objectives pursued in response to the obstacles (Hofmann \& Vohs, 2016) as well with the assumption that people are more familiar with problematic goal striving rather than unattainable goals (in the strict sense) - especially in younger age and general population without disastrous health issues. On the other hand, it may also be one of the reasons why the current research was not fully in line with the assumed pattern of relationships (Wrosch et al., 2003).

In the present research, it has been shown that goal adjustment capacities do not necessarily correlate positively with the indicators of subjective well-being. Rather, the results of the current research have shown that an increased level of goal disengagement capacity is related to less dispositional optimism, hope and self-regulation. While the relationships were significant, they were rather modest in magnitude. At the same time, there was no significant relationship with either positive or negative state of mind. In the case of goal reengagement capacity, there was only one positive and significant but rather modest correlation with the factor of disposition hope the factor Pathway. This factor represents the perception of possible ways to meet goals. Similar results have been found by Wrosch et al. (2013) in that goal disengagement has demonstrated a stronger relationship with the negative aspects of subjective well-being than the positive ones. The present findings, as well as the results of some recent studies (Wrosch \& Sabiston, 2013; Nicholls et al., 2016), have shown that the associations between goal adjustment capacities and aspects of subjective well-being are often low or absent. In this case, however, the effect of age could also be manifested, because e.g., Barlow et al. (2020) state in their study that especially the beneficial associations of goal disengagement and indicators of quality of life were stronger in samples of older, as compared to younger population. Therefore, we consider age as a potentially important moderator and deliberate inclusion of older respondents to be an important element of future research.

As previously mentioned, the original GAS scale instruction was related to unattainable goals and research was mainly conducted on respondents, who were exposed to life situations where using a goal adjustment strategy could provide relief. For instance, in the young population, goal disengagement seems to cause a decrease in subjective well-being (similar to Soubrier et al., 2017) and is associated with weaker markers of resilience. According to Arends et al. (2013), it seems that in the case of goal disengagement there is the 
benefit of a new alternative goal that would reduce its consequences.

Based on our findings, we can conclude that the Slovak version of the GAS has an adequate internal structure. Our results bring the most empirical support for the theoretical model which assumes 2 mutually correlated factors. This pattern of results is consistent with the original concept of goal adjustment capacity (specifically factor structure) (Wrosch et al., 2003a, b) and with the current findings on the connection of the two factors of the scale (Barlow et al., 2020; Soubrier et al., 2017). Regarding validity, due to inconsistent results in the case of well-being, we recommend using criteria with more consistent and stable effects in further validation studies. The current results are only preliminary and generally illustrate the complexity of the relationships between adjustment strategies and consequences (and also the antecedents) for well-being and lead to the need to focus on clarifying the mitigating and mediating factors of these relationships.

\section{Limitations}

There are certain limitations of the present research. Firstly, in spite of some merits of using ULSMV estimator over ML (maximum likelihood), inherent limitations are present in this approach. For example, Xia and Yang (2019) have noted that when using alternative estimators (such as ULS and DWLS), the conventionally used cut-off scores based on the Maximum likelihood estimator could be biased and provide falsely better model-data fit in comparison to the classic ML estimator. Although this issue is reflected upon, conventional criteria were used, as the accepted specific cut-off criteria for alternative estimators are not widely received. However, this limitation needs to be reflected upon even beyond the present research and rather than focusing on strict and dichotomizing cut-off criteria, a more nuanced approach is necessary when interpreting the results of present and future studies using SEM.

Another inherent limitation is the self-reporting character of the scale and the fact that the test-retest reliability was not ascertained. At the same time, we are aware that it would be appropriate to conduct research on adults or seniors and compare the results with the ones we obtained on young people. This is considered to be perspective in further research. It is considered important to perform further validation of the GAS as the current results are only preliminary and aimed to encourage future research into the topic.

\section{Acknowledgements}

This study was supported by Research and Development support Agency under the contract No. APVV-19-0284, VEGA 1/0748/19.

\author{
Authors' ORCID \\ Beáta Ráczová \\ https://orcid.org/0000-0003-2110-0871 \\ Pavol Kačmár \\ https://orcid.org/0000-0003-0076-1945 \\ Monika Hricová \\ https://orcid.org/0000-0001-9873-5475
}

\section{References}

Arends, R. Y., Bode, C., Taal, E., \& Van de Laar, M. A. (2013). The role of goal management for successful adaptation to arthritis. Patient Education and Counselling, 93, 130-138. https://doi. org/10.1016/i.pec.2013.04.022

Barlow, M., Wrosch, C., \& McGrath, J. J. (2020). Goal adjustment capacities and quality of life: A meta-analytic review. Journal of Personality, 88(2), 207-323. https://doi.org/10.1111/ jopy. 12492

Carver, C. S., \& Scheier, M. (1990). Principles of self-regulation: Action and emotion. In E. T. Higgins \& R. M. Sorrentino (Eds.), Handbook of 
motivation and cognition: Foundations of social behaviour, Vol. 2 (pp. 3-52). The Guilford Press.

Carver C. S, \& Scheier M. F. (1998). On the self-regulation of behaviour. New York: Cambridge University Press.

Džuka, J., \& Dalbert, C. (2002). Vývoj a overenie validity škál emocionálnej habituálnej subjektívnej pohody (SEHP). Československá Psychologie, 46(3), 234-250.

Field, A. (2017). Discovering statistics using IBM SPSS statistics (5th ed.). Thousand Oaks, CA: SAGE Publications

Funder, D. C., \& Ozer, D. J. (2019). Evaluating effect size in psychological research: Sense and nonsense. Advances in Methods and Practices in Psychological Science, 2(2), 156-168. https:// doi.org/10.1177/2515245919847202

Halama, P. (2001). Slovenská verzia Snyderovej Škály nádeje: Preklad a adaptácia. Československá Psychologie, 45(2), 135-141.

Halama, P. (2011). Princípy psychologickej diagnostiky. Trnavská Univerzita.

Hansen, M. J., Trujillo, D. J., Boland, D. L., \& MacKinnon, J. L. (2014). Overcoming obstacles and academic hope: An examination of factors promoting effective academic success strategies. Journal of College Student Retention: Research, Theory \& Practice, 16(1), 49-71. https://doi. org/10.2190/CS.16.1.C

Heckhausen, J., Wrosch, C., \& Schulz, R. (2010). A motivational theory of life-span development. Psychological Review, 117(1), 32-60. https:// doi.org/10.1037/a0017668

Hofmann, W., \& Vohs, K. D. (2016). Desire and selfregulation. Handbook of self-regulation: Research, theory, and applications, 3, 204-226.

Hooper, D., Coughlan, J., \& Mullen, M. (2008). Structural equation modelling: Guidelines for determining model fit. Electronic Journal of Business Research Methods, 6(1), 53-60.

Kline, R. B. (2016). Principles and practice of structural equation modelling (Fourth edition). New York: Guilford publications.

Kogar, H., \& Kogar, E. Y. (2015). Comparison of different estimation methods for categorical and ordinal data in confirmatory factor analysis. Eğitimde ve Psikolojide Ölçme ve Değerlendirme Dergisi, 6(2), 351-364. https://doi.org/10.21031/ epod.94857
Köverová, M., \& Ferjenčík, J. (2013). Adaptácia a orientačné overovanie psychometrických charakteristík testu životnej orientácie LOT-R. Československá Psychologie, 57(5), 461-473.

Lam, W. W., Yeo, W., Suen, J., Ho, W. M., Tsang, J., Soong, I., ... \& Kwong, A. (2016). Goal adjustment influence on psychological well-being following advanced breast cancer diagnosis. Psycho-Oncology, 25(1), 58-65. https://doi.org/10.1002/ pon. 3871

Leys, C., Delacre, M., Mora, Y. L., Lakens, D., \& Ley, C. (2019). How to classify, detect, and manage univariate and multivariate outliers, with emphasis on pre-registration. International Review of Social Psychology, 32(1), 5. https://doi. org/10.5334/irsp.289

Mens, M. G., Scheier, M. F., \& Wrosch, C. (2016). Goal adjustment theory. In S. Krauss Whitbourne (Ed.), The Encyclopedia of Adulthood and Aging, 1-5. First Edition. John Wiley \& Sons, Inc. https:// doi.org/10.1002/9781118521373.wbeaa192

Nicholls, A. R., Levy, A. R., Carson, F., Thompson, M. A., \& Perry, J. L. (2016). The applicability of self-regulation theories in sport: goal adjustment capacities, stress appraisals, coping, and well-being among athletes. Psychology of Sport and Exercise, 27, 47-55. https:// doi.org/10.1016/i.psychsport.2016.07.011

O'Connor, R. C., Fraser, L., Whyte, M. C., MacHale, S., \& Masterton, G. (2009). Self-regulation of unattainable goals in suicide attempters: The relationship between goal disengagement, goal reengagement and suicidal ideation. Behaviour Research and Therapy, 47(2), 164-169. https://doi.org/10.1016/i. brat.2008.11.001

Ramírez-Maestre, C., Esteve, R., López-Martínez, A. E., Serrano-Ibáñez, E. R., Ruiz-Párraga, G. T., \& Peters, M. (2019). Goal adjustment and well-being: The role of optimism in patients with chronic pain. Annals of Behavioral Medicine, 53(7), 597-607. https://doi.org/10.1093/abm/kay070

Rasmussen, H. N., Wrosch, C., Scheier, M. F., \& Carver, C. S. (2006). Self-regulation processes and health: The importance of optimism and goal adjustment. Journal of Personality, 74(6), 1721-1748. https:// doi.org/10.1111/i.1467-6494.2006.00426.x

Schroevers, M. J., Kraaij, V., \& Garnefski, N. (2011). Cancer patients' experience of positive and negative changes due to the illness: Relationships with psychological well-being, coping, and goal 
reengagement. Psycho-Oncology, 20(2), 165172. https://doi.org/10.1002/pon.1718

Soper, D. S. (2019). A-priori sample size calculator for structural equation models [Software]. Available from http://www.danielsoper.com/statcalc

Soubrier, E., Esteve, R., \& Ramírez-Maestre, C. (2017). Adaptación de las escalas "Tenacious Goal Pursuit and Flexible Goal Adjustment" y "Goal Disengagement and Goal Reengagement". Escritos de Psicología, 10(2), 103-115. https:// doi.org/10.5231/psy.writ.2017.2003

Šebeňa, R., Orosová, O., Helmer, S., Petkeviciene, J., Salonna, F., Lukacs, A., \& Mikolajczyk, R. (2018). Psychometric evaluation of the Short Self-Regulation Questionnaire across three European countries. Studia Psychologica, 60(1), 5-15. https://doi.org/10.21909/sp.2018.01.748 Team, R. C. (2017). R Core Team (2017). R: A language and environment for statistical computing. R Found. Stat. Comput. Vienna, Austria. URL http://www. R-project. org/., page R Foundation for Statistical Computing. R Core Team. (2017). R: A Language and Environment for Statistical Computing. Available from https://www.R-project.org/

Van Damme, S., Kindt, S., Crombez, G., Goubert, L., \& Debruyne, J. (2019). The relation between goal adjustment, goal disturbance, and mental well-being among persons with multiple sclerosis. Psychology \& Health, 34(6), 645-660. https://doi.org/10.1080 $\angle 08870446.2018 .1556272$

Wrosch, C., Amir, E., \& Miller, G. E. (2011). Goal adjustment capacities, coping, and subjective well-being: The sample case of caregiving for a family member with mental illness. Journal of Personality and Social Psychology, 100(5), 934946. https://doi.org/10.1037/a0022873

Wrosch C., Miller G. E., Scheier M. F., \& Pontet S. B. (2007). Giving up on unattainable goals: Benefits for health? Personality and Social Psychology Bulletin, 33(2), 251-265. https://doi. org/10.1177/0146167206294905

Wrosch, C., \& Sabiston, C. M. (2013). Goal adjustment, physical and sedentary activity, and wellbeing and health among breast cancer survivors. Psycho-Oncology, 22(3), 581-589. https://doi. org/10.1002/pon.3037

Wrosch, C., Scheier, M. F., \& Miller, G. E. (2013). Goal adjustment capacities, subjective well-being, and physical health. Social and Personality Psychology Compass, 7(12), 847-860. https:// doi:10.1111/spc3.12074

Wrosch, C., Scheier, M. F., Carver, C. S., \& Schulz, R. (2003a). The importance of goal disengagement in adaptive self-regulation: When giving up is beneficial. Self and Identity, 2(1), 1-20. https:// doi.org/10.1080/15298860309021

Wrosch, C., Scheier, M. F., Miller, G. E., Schulz, R., \& Carver, C. S. (2003b). Adaptive self-regulation of unattainable goals: Goal disengagement, goal reengagement, and subjective well-being. Personality and Social Psychology Bulletin, 29(12), 1494-1508. https://doi.org/10.1177/0146167203256921

Zhang, Z., \& Yuan, K.-H. (2018). Practical statistical power analysis using Webpower and $R$ (Eds). Granger, IN: ISDSA Press. 


\section{Appendix}

\section{Škála adaptívnej zmeny ciela}

\section{Inštrukcia:}

L'udia počas svojho života nedokážu vždy dosiahnut' to, čo chcú alebo pocitujujú rôzne prekážky na ceste k ciel'om, ktoré si stanovili. Zaujíma nás, ako obvykle reaguješ, ked'sa Ti to stane. Označ mieru súhlasu alebo nesúhlasu s každým z nasledujúcich tvrdení podl'a toho, ako vystihujú Tvoje obvyklé správanie v tejto situácii.

Škála:

vôbec nesúhlasím 12345 úplne súhlasím

Položky:

1. Jednoducho svoju snahu o dosiahnutie tohto ciel'a znížim

2. Presviedčam sám seba, že mám ešte d'alšie zmysluplné ciele, ktoré sa môžem snažit' dosiahnut'.

3. Dlho zostanem na tento ciel' zameraný/á, neviem sa ho vzdat'

4. Začnem pracovat' na d'alších nových ciel'och

5. Premýšl'am o d'alších nových ciel'och, ktoré sa môžem snažit' dosiahnut'

6. Pripadá mi t'ažké prestat' sa usilovat' o dosiahnutie tohto ciel'a

7. Hladám d’alšie zmysluplné ciele

8. Jednoducho prestanem o tomto cieli uvažovat' a vzdám sa ho.

9. Hovorím si, že mám ešte množstvo d’alších nových ciel'ov, z ktorých môžem čerpat'.

10. Svoje úsilie zameriam na d’alšie zmysluplné ciele.

Informácie:

Škála je tvorená dvoma subškálami:

1) upustenie od ciel'a/vzdanie sa ciel'a - 4 položky (položky 1, 3, 6, 8, pričom 3 a 6 je potrebné prepólovat'). Zahŕňajú upustenie od záväzku a zniženie úsilia.

2) zapojenie sa do nových ciel'ov - 6 položiek (položky 2, 4, 5, 7, 9, 10). Zahŕňajú tendenciu identifikovat' nové ciele, zaviazat' sa k novému ciel'u a začatie aktívneho dosahovania ciela. 